\title{
Farmers' challenges on chili farming in the acid dry land : A case study from Pasir Madang- Bogor Regency, Indonesia
}

\author{
Asma Sembiring ${ }^{*}$, Rofik Sinung Basuki, Rini Rosliani, and Suwarni Tri Rahayu \\ Indonesian Vegetables Research Institute, Lembang-Bandung, Indonesia
}

\begin{abstract}
Chili has become a high-value economic commodity in Indonesia. Indonesian chili consumption is increasing every year. In order to fulfill the demand, chili commonly is planted on fertile land. Meanwhile, Indonesia has a vast less fertile land, such as the acid dry land that has not been utilized for a long time. This land can be utilized to plant chili. However, there are many challenges to be faced that need to be solved. The study aims to identify farmers' challenges on chili farming an acid dry land, viewed from social-economic aspects, natural conditions, biology, and land. The study was conducted from April to October 2016 in Pasir Madang, Sukajaya sub-district, Bogor, Indonesia. About 49 chili farmers were involved in the study. Data were analyzed descriptively. The results of the study showed that the farmers planted chili because it was profitable. Area for planting chili commonly less fertile/infertile. To solve the problem, farmers used manure and chemical fertilizers. Meanwhile, challenges faced by the chili farmers were pest and disease attacks. Other obstacles were capital, farmers' knowledge on chili cultivation, and choosing effective and efficient fungicides and insecticides to control the chili pests and diseases.
\end{abstract}

\section{Introduction}

Chili is a high-value vegetable commodity that is important both from economic and consumption necessity fulfillment for Indonesian people. From 2015 to 2018 , national chili production, consisted of chili and bird's eye chili, increased by $30.45 \%$ or on average 7.61 $\%$ per year, from 1,915,154 tons in 2015 to 2,542,358 tons in 2018 [1]. Meanwhile, productivity also rose by about $9.88 \%$ from 2015 to 2018 , with an average growth of $2.47 \%$ per year.

As an increase in population and income, chili consumption also increases every year. To fulfill the consumption, chili production is needed to be added. All this time, the increase of chili production has been conducted through planting chili on fertile lands. Meanwhile, there is a lot of less fertile land (sub-optimal such as acid dry land in Indonesia widely available [2], achieved 107.36 million hectares [3]. Nevertheless, the land has been not utilized optimally.

\footnotetext{
*Corresponding author: rangkayoamah@gmail.com
} 
An effort to increase the acid dry land utilization is a necessity to be conducted, such as by planting the land with chili. Nevertheless, there are a lot of obstacles needed to be solved in utilizing the acid-dry land. To understanding the problems, therefore it is needed to identify farmer's challenges in managing chili farming in the acid dry land. Hence, the proper solutions, especially solutions to increase chili production on the land could be found. Farmer's problems are related to the internal social-economic aspects (such as target, risk, natural resource obstacles), external aspects (input-output market, institution), and natural conditions that covers climate (rainfall, temperature) [4][5], plant's pests, and diseases and land [6][7].

The study aims were to identify challenges related to social-economic, natural conditions, biology, and land that is faced by farmers in conducting their chili farming in the acid dry land. Results of the study are expected to overcome farmers' obstacles to increasing chili production in the acid dry land.

\section{Research Methods}

The study was conducted from April to October 2016 in Pasir Madang, Sukajaya subdistrict, Bogor West Java. A location research area was selected based on the following criteria: 1) the traditional chili production area, 2) the kind of soil is a Red-Yellow Podsolik with soil's pH less than 5, and 3) They were available more than 30 chili farmers in the area.

The research method was used Focus Group Discussion (FGD) and survey. Eight persons who knew the general picture of the chili farming system in Pasir Madang was involved in FGD. Also, the challenges faced by the farmer in conducting the chili farming. The FGD's results then were used as a basis to arrange a questioner for a formal survey.

Forty-nine chili farmers who were selected purposively were involved in the survey. The respondents were chosen based on the criteria that the respondents had experience in chili planting more than one year and still planting chili at the time of the survey. Data were collected covering: a) social-economic respondent's characteristics: name, age, formal education, main job, side job, size and land area status, families burdens b) chili farming that had been conducted: farming's experience, reasons for running farming, soil fertility and kind of soil that used for chili farming, chili varieties that were used, planting size, challenges on chili farming covering: economic obstacles (farmer's target, land resource's obstacles, labor, and capital, market input and output, institution); natural obstacles (climate, biology such as pests and diseases, and the problem of soil type) c) kinds, number, input, and output prices in chili farming). Data were analyzed descriptively, using a table and rank system.

\section{Results and Discussions}

\subsection{Respondent's characteristics}

The majority of the respondents $(66 \%)$ were between 41 to 60 years old, and most of them were in elementary school (Table 1). In terms of Chili planting experience, about $64 \%$ of respondents had planted chili more than one year and less than ten years.

The main farmers' occupation was HGU tenant farmer, owned by the government. HGU stands for the right to attempt to. Of this, $63 \%$ had a side job as labor or small cattleman. Most farmers' chili cultivation area $(80 \%)$ was under $2000 \mathrm{~m}^{2}$ (Table 2). They had planted chili in the study area since 2001 . 
According to Rahma et al., [8], a higher education person is faster to accept innovation. As most respondents' education was elementary school, these can be categorized as the lower education and indicated as the slow innovation acceptor.

Table 1. Respondent's characteristics

\begin{tabular}{|l|c|c|}
\hline Characteristics & Number of respondents & Percentage (\%) \\
\hline Age (Year) $(\mathbf{n}=\mathbf{4 9 )}$ & 3 & 6 \\
\hline $21-30$ years old & 10 & 20 \\
\hline $31-40$ years old & 15 & 31 \\
\hline $41-50$ years old & 17 & 35 \\
\hline $51-60$ years old & 4 & 8 \\
\hline $61-70$ years old & & 14 \\
\hline Formal education $(\mathbf{n}=\mathbf{4 9 )}$ & 7 & 76 \\
\hline Not attend the school & 37 & 8 \\
\hline Elementary school & 4 & 2 \\
\hline Junior high school & 1 & 0 \\
\hline Senior high school & 0 & 98 \\
\hline University & & 0 \\
\hline Main jobs $(\mathbf{n}=\mathbf{4 9 )}$ & 48 & 2 \\
\hline HGU Tenant farmer & 0 & \\
\hline Tenant share farmer & 1 & \\
\hline Sharecroppers & & \\
\hline
\end{tabular}

\subsection{Farmers' reasons for planting chili}

Several farmers' reasons for planting chili were profit, habit, the chili price and market demand. In this study, the first reason for farmers planted chili were profitable (34\%),

Table 2. Farmers' reasons for planting chili

\begin{tabular}{|l|c|c|}
\hline Farmers' reasons & Number of respondents & Percentage (\%) \\
\hline a. Profitable compared to other crops & 17 & 34 \\
\hline b. The selling price higher & 15 & 31 \\
\hline c. Market demand & 2 & 4 \\
\hline d. Habit & 15 & 31 \\
\hline Total & 49 & 100 \\
\hline
\end{tabular}

followed by the chili selling price was higher than other vegetables (31\%) and habit $(35 \%)$ (Table 2). The farmers assumed that they got more income by producing chili compared to other crops. This finding is supported by a previous that said chili farming is still profitable [9]. A profit is an ultimate factor that considers by a farmer when deciding to plant certain crops or using technology cultivations [10][11].

\subsection{Kinds of chili planted by farmers}

The farmers planted two chili varieties; they were bird's eye chili and curly chili. The majority of farmers (88\%) were planted curly chili. This type of chili was included TM 99, local, and Bintang Asia. The farmers used TM 99 allegedly it had high productivity and was resistant to several diseases [12]. A few of them also planted a local variety of bird's eye chili, and none has planted the large chili (Table 3). According to farmers, the chili was not suitable planted in their land as it was quickly attacked by Phytophthora capsici and died. 
Table 3. Kinds of chili planted by farmers

\begin{tabular}{|l|c|c|}
\hline \multicolumn{1}{|c|}{ Kinds of chili } & \multicolumn{1}{|c|}{$\begin{array}{c}\text { Number of } \\
\text { respondents }\end{array}$} & $\begin{array}{c}\text { Percentage } \\
\text { (\%) }\end{array}$ \\
\hline Bird's eye chili (local, setan) & 9 & 18 \\
\hline $\begin{array}{l}\text { Curly chili ( TM 99, Local and Bintang } \\
\text { Asia) }\end{array}$ & 43 & 88 \\
\hline A chili (the large chili) & 0 & 0 \\
\hline Total & 49 & 100 \\
\hline
\end{tabular}

\subsection{Types of soils that planted chili by farmers}

Farmers planted chili in three types of soil color; they were black, brown and reddish. The majority of them planted chili on reddish color soil (67\%), followed by brown color. It is perceived as less fertile and infertile land (Table 4).

Table 4. Color and farmer's soil fertilization level that planted chili

\begin{tabular}{|l|c|c|}
\hline Soil color & Number of respondents & Percentage (\%) \\
\hline Black & 6 & 12 \\
\hline Brown & 10 & 20 \\
\hline Reddish & 33 & 67 \\
\hline Total & 49 & 100 \\
\hline Soil fertilization & & \\
\hline Fertile & 3 & 7 \\
\hline Less fertile & 25 & 54 \\
\hline infertile & 18 & 39 \\
\hline Total & 46 & 100 \\
\hline
\end{tabular}

Challenges that appeared when planting chili in this land were stunted plants, low productivity, and small fruit. Farmer's land in Pasir Madang Bogor could be grouped as acid dry land with a $\mathrm{pH}$ of around 5 and poor nutrients. The soil type contains less $\mathrm{P}, \mathrm{K}$, and other nutrients, causing low productivity [13]. A previous study also showed that soil acidity restricted the growth and the production of various crops [14].

To increase the soil fertility, the majority of farmers (88\%) gave manure, some of them (about 57\%) added chemical fertilizers, and a few of them (8\%) used lime as well as manure altogether. Interestingly, none of the farmers specifically used lime for their soil. It happened as they had not got any information or were not aware of the lime benefits of increasing soil $\mathrm{pH}$. Adding lime could increase soil $\mathrm{pH}$, also improve yield and crop quality [15].

\subsection{Challenges on chili farming in acid dry land}

Among several aspects such as getting land, irrigation, access to facilitation, marketing, capital, controlling pests and diseases and farmers' knowledge on chili cultivation, the respondents had challenges controlling pests and diseases, capital and farmers' knowledge on chili cultivation technology.

\subsubsection{Challenges on pests and diseases of chili farming}

Farmers recognized several pests and diseases that attacked their chili plant. According to the farmers, the common pests that were often attacking chili and very difficult to be 
controlled were fruit flies and Thrips. Meanwhile, a common disease was Anthracnose (Table 5). Those three kinds are the ultimate pests and diseases quite often attacking the chili plant, cause yield losses and degrade the chili yield [16][17][18].

Table 5. Challenges on chili pests and diseases

\begin{tabular}{|l|c|c|c|c|}
\hline \multirow{2}{*}{ Kinds of pests } & \multicolumn{2}{|c|}{ Often attack* } & \multicolumn{2}{c|}{ Difficult to control* } \\
\cline { 2 - 5 } & $\mathbf{n}$ & $\mathbf{\%}$ & $\mathbf{n}$ & $\mathbf{\%}$ \\
\hline Curly leaf pest & 15 & 31 & 5 & 10 \\
\hline Thrips & 23 & 47 & 17 & 35 \\
\hline Mites & 15 & 31 & 11 & 22 \\
\hline Aphids & 15 & 31 & 7 & 14 \\
\hline Fruit flies & 30 & 61 & 28 & 57 \\
\hline Worm & 10 & 20 & 2 & 4 \\
\hline Total & 49 & 100 & 49 & 100 \\
\hline
\end{tabular}

*) The respondents could answer more than one answer

\subsubsection{Challenges on the capital of chili farming}

Lack of capital often happened to the majority of farmers (71\%) during conducted chili farming (Table 6), especially to buy inputs such as pesticides, fertilizer and pay labor. Capital deficiency is a common obstacle that farmers were facing as they got low profit [19]. It also often becomes a challenge for farmers to expand their business [20]. In Indonesia, farmers are small farmers and subsistence, and they are allocated capital from a previous harvest.

Table 6. Challenges on the capital and Farmers' knowledge on chili cultivation technology $(n=49)$

\begin{tabular}{|c|l|l|c|c|}
\hline No & Kinds of challenges & \multicolumn{1}{|c|}{$\begin{array}{c}\text { Farmers' } \\
\text { opinion }\end{array}$} & $\begin{array}{c}\text { Number of } \\
\text { respondents }\end{array}$ & $\begin{array}{c}\text { Percentage } \\
\text { (\%) }\end{array}$ \\
\hline 1 & Capital & a. Yes, often & 35 & 71 \\
\cline { 3 - 5 } & & $\begin{array}{l}\text { b. Yes, } \\
\text { sometimes }\end{array}$ & 13 & 27 \\
\cline { 3 - 5 } & & c. Never & 1 & 2 \\
\hline 2 & $\begin{array}{l}\text { Chili farmer's planting } \\
\text { knowledge }\end{array}$ & a. Less & 48 & 98 \\
\cline { 3 - 5 } & b. Enough & 1 & 2 \\
\hline
\end{tabular}

To solve the problem of capital restriction, the respondents borrow money. However, rather than borrow from the bank or other formal institution finances, they preferred to borrow from their family, neighbours, input traders or selling their cattle. It was because they did not understand a procedure to propose the loan or the procedure to request a loan was complicated [21][22] and needed collateral in which they could not fulfil [23].

\subsubsection{Challenges on chili cultivation technology knowledge}

Table 6 presented that farmers had obstacles to chili cultivation technology. The majority of respondents (98\%) acknowledged that their knowledge to control chili pests and diseases was limited, especially in choosing efficacious fungicides (71\%) and insecticides $(63 \%)$ (Table 7).

Meanwhile, there were no challenges in getting land, irrigation, access to facilitation, and marketing. In terms of land, most respondents (82\%) said that there was no obstacle to 
getting land for chili planting as they got an arable land quota from a government in the form of a right to cultivate (HGU).

Table 7. Farmers' obstacles on chili cultivation technology

\begin{tabular}{|l|c|c|}
\hline \multicolumn{1}{|c|}{ Farmers' challenges } & \multicolumn{1}{|c|}{$\begin{array}{c}\text { Number of } \\
\text { respondents }\end{array}$} & $\begin{array}{c}\text { Percentage } \\
\text { (\%) }\end{array}$ \\
\hline a. Land management & 4 & 8 \\
\hline b. The way to measure kinds and fit dosage for lime & 6 & 12 \\
\hline $\begin{array}{l}\text { c. The way to determine kinds and fit dosage for } \\
\text { manure }\end{array}$ & 16 & 33 \\
\hline $\begin{array}{l}\text { c. The way to determine kinds and fit dosage for } \\
\text { chemical fertilizers }\end{array}$ & 19 & 39 \\
\hline e. The way to choose efficacious insecticides & 31 & 63 \\
\hline f. The way to choose efficacious fungicides & 35 & 71 \\
\hline g. The best way to spray & 13 & 27 \\
\hline h. others & 7 & 14 \\
\hline Total & 49 & 100 \\
\hline
\end{tabular}

Regarding irrigation, about $59 \%$ of respondents stated that there was no obstacle to irrigation. Those who had the obstacle on chili irrigation $(12 \%)$ said that the problem appeared because they depended on the rain and had no technical irrigation tunnel in their area.

Regarding access to production facilities, the respondents said that their location was relatively accessed by public transportation, connecting it to sub-district towns or other villages. Regarding production facilities, input production kiosks were available in the subdistrict, other villages, and the study area. Therefore, most of the respondents (69\%) said that no obstacle to access them in terms of production facilities.

The majority of farmers $(88 \%)$ also stated that they did not have chilli marketing problems. There were many public transportations available in the village toward the subdistrict traditional market, even though toward Bogor district traditional market. Besides that, intermediaries often contacted and came to farmers directly to purchase the farmers' yield when harvesting time.

\section{Conclusion}

To sum up, in developing chili farming on acid dry land, farmers had some challenges in controlling pests and diseases, capital and knowledge on chili cultivation technology. In order to address the challenges, it is needed to introduce knowledge to farmers to choose effective and efficient fungicides and insecticides, precisely to control thrips, fruit flies and anthracnose, as well as to open farmers access to simple and practical funding institutions.

We thank the Indonesian IAARD for funding the research

\section{References}

1. Badan Pusat Statistik (BPS), Statistik Indonesia 2019, Jakarta, Indonesia, 264 (2019).

2. H. Kuswantoro, BIOTROPIA. 23 (1) 52 (2016).

3. A. Dariah, N. Heryani, Jurnal Sumberdaya Lahan. 1 (2014).

4. A. Mekonnen, A. Tessema, Z. Ganewo, A. Haile, Journal of Agriculture and Food 
Research. 6, 1 (2021)

5. N.B. Holmelin, Journal of Rural Studies. 83, 71 (2021).

6. J.O. Okonya, W. Ocimati, A. Nduwayezu, D. Kantungeko, N. Niko, G. Blomme, J.P. Legg, J. Kroschel, Sustainability. 11, 1 (2019).

7. D.O. Pribadi, I. Zasada, K. Mulluer, S. Pauleit, Journal of Rural Studies. 55, 100 (2017).

8. P.R. Pratiwi, S.I. Santoso, W. Roessali, Jurnal Agraris. 4(1), 9 (2018)

9. R. Hartono, H.B. Astuti, Proceeding International Seminar on Promoting Local Resources for Food and Health, University of Bengkulu, Indonesia, 524-527 (2016).

10. R.T. Jatuningyas, D. Prasetianti, J. Triastono, Proceeding of International Symposia on Horticulture (ISH) 2018, Indonesian Center for Horticulture Research and Development, Bali, Indonesia, 91-98 (2019).

11. I.K. Mahaputra, N.N. Arya, J. Rinaldi, Proceeding of International Symposia on Horticulture (ISH) 2018, Indonesian Center for Horticulture Research and Development, Bali, Indonesia, 207-213 (2019).

12. L. Rahayu, D. Febriani, E3S Web of Conferences, Universitas Muhammadiyah Yogyakarta, Yogyakarta, Indonesia, 1-11 (2021)

13. Prihastuti, Sudaryono, J. Trop Soils. 18 (1), 17 (2013).

14. A.N. Ganeshamurthy, A.N. Kalaivanan, G.C. Satisha, Innovations in Horticultural Sciences, New Delhi, India 559-584 (2016).

15. T. Ameyu, Journal of Environment and Earth Sciences. 9 (2), 17 (2019)

16. A. Johari, S. Herlinda, C. Irsan, Y. Pujiastuti, American Journal of Agricultural and Biological Sciences. 11 (3), 103 (2016).

17. F. Jamaluddin, A. Nurariaty, N. Amin, Earth and Environmental Science 486, 1-7 (2020).

18. R.R. Manda, G. Pavithra, V.A. Addauki, S. Srivastava, International Journal of Current Microbiology and Applied Science. 9 (11), 749 (2020).

19. Amanullah, G.R. Lakhan, S.A. Channa, H. Magsi, M.A. Koondher, J. Wang, N.A. Channa, Heliyon. 6, 1 (2020).

20. A. Sembiring, R.R. Murtiningsih, Kusmana, Journal of Agribusiness and Rural Development Research. 7 (1), 78 (2021)

21. A.A. Rudiyanto, Journal of Economics and Policy. 7 (2), 175 (2014).

22. A. Jamal, S.S. Mazhar, International Journal of Research and Analytical Reviews. 6 (1), 144 (2019).

23. J. Mariyono, Journal of Entrepreneurship in Emerging Economics. 11 (1), 98 (2018). 